\title{
Artur Mikulec
}

Uniwersytet Łódzki

e-mail: amikulec@uni.lodz.pl

SZACOWANIE WYBRANYCH PARAMETRÓW ROZKLADU CZASU TRWANIA I WARUNKOWEGO ROZKLADU CZASU TRWANIA PRZEDSIĘBIORSTW W WOJEWÓDZTWIE LÓDZKIM

\section{ESTIMATION OF SELECTED PARAMETERS OF DISTRIBUTION OF TIME DURATION AND CONDITIONAL DISTRIBUTION OF TIME DURATION OF ENTERPRISES IN LODZKIE VOIVODSHIP}

DOI: $10.15611 / \mathrm{pn} .2018 .507 .17$

JEL Classification: C10, C14, C41

Streszczenie: $\mathrm{W}$ analizie trwania przedsiębiorstw oprócz podstawowych funkcji charakterystycznych, tj.: funkcji gęstości - prawdopodobieństwa likwidacji przedsiębiorstwa; dystrybuanty - prawdopodobieństwa dotrwania przedsiębiorstwa; funkcji przetrwania - prawdopodobieństwa przetrwania przedsiębiorstwa oraz funkcji hazardu - intensywności likwidacji przedsiębiorstwa, szacować można parametry rozkładu czasu trwania i warunkowego rozkładu czasu trwania przedsiębiorstw. W artykule przedstawione zostały zagadnienia teoretyczne i praktyczne wyznaczania: mediany czasu trwania przedsiębiorstw (czasu półtrwania) oraz mediany dalszego czasu trwania przedsiębiorstw. Rozważania zilustrowane zostały obliczeniami wyżej wymienionych miar dla kolejnych kohort przedsiębiorstw powstałych (w tym zlikwidowanych) w województwie łódzkim w latach 2001-2015.

Słowa kluczowe: mediana czasu trwania przedsiębiorstw (czas półtrwania), mediana dalszego czasu trwania przedsiębiorstw, województwo łódzkie, Łódź, Piotrków Trybunalski, Skierniewice.

Summary: In the analysis of duration of enterprises not only basic functions are estimated, i.e. density function - probability of liquidation of enterprise; cumulative distribution function - probability of the company's survival; survival function - probability of survival of enterprise and hazard function - intensity of liquidation of enterprise; also parameters of distribution of time duration of enterprises and conditional distribution of time duration of enterprises can be estimated. The article presents theoretical and practical aspects of determining: median duration of enterprises (half-life of the groups) and median additional duration of enterprises. The reflections are illustrated with calculations for the enterprises in the 
Lodzkie Voivodship on the basis of cohort data on enterprises established in the Lodzkie Voivodship in the years 2001-2015 (including liquidated).

Keywords: median of duration of enterprises (half-life of the groups), median of additional duration of enterprises, Lodzkie Voivodship, Lodz, Piotrkow Trybunalski, Skierniewice.

\section{Wstęp}

Analiza kohortowa czasu trwania przedsiębiorstw jest analizą jednej i tej samej kohorty i polega na obserwowaniu zmian, jakie zachodzą w jej składzie w czasie. W tablicach kohortowych oprócz podstawowych funkcji, tj.: gęstości - prawdopodobieństwa likwidacji przedsiębiorstwa; dystrybuanty - prawdopodobieństwa dotrwania przedsiębiorstwa; przetrwania - prawdopodobieństwa przetrwania przedsiębiorstwa oraz funkcji hazardu - intensywności likwidacji przedsiębiorstwa, można szacować parametry (charakterystyki) rozkładu czasu trwania i warunkowego rozkładu czasu trwania przedsiębiorstw.

Celem pracy jest przedstawienie teoretycznych i praktycznych aspektów wyznaczania: mediany czasu trwania przedsiębiorstw (czas półtrwania) oraz mediany dalszego czasu trwania przedsiębiorstw na podstawie tablic kohortowych. Rozważania teoretyczne zilustrowane zostaną obliczeniami dla przedsiębiorstw powstałych $\mathrm{w}$ latach 2001-2015 w województwie łódzkim, w tym w trzech miastach na prawach powiatu: Łodzi, Piotrkowie Trybunalskim i Skierniewicach.

\section{Charakterystyka danych}

W analizie wykorzystano dane jednostkowe o 265,3 tys. przedsiębiorstwach powstałych w województwie łódzkim w latach 2001-2015 (tab. 1). Spośród nich 102,1 tys. przedsiębiorstw rozpoczęło działalność gospodarczą w Łodzi, 8,8 tys. w Piotrkowie Trybunalskim, a 5,3 tys. w Skierniewicach. Przy budowie tablic kohortowych niezbędne były także szczegółowe dane o przedsiębiorstwach zlikwidowanych według roku powstania - województwo łódzkie - 115,6 tys., w tym: Łódź - 41,3 tys., Piotrków Trybunalski $-3,9$ tys. oraz Skierniewice $-2,3$ tys.

Dane o przedsiębiorstwach zostały pozyskane z Urzędu Statystycznego w Łodzi i zawierały: REGON, lokalizację, formę własności, formę prawną, PKD, odpowiednio datę powstania przedsiębiorstwa i/lub datę zakończenia działalności gospodarczej oraz wielkość przedsiębiorstwa - mierzoną liczbą osób pracujących podaną przedziałowo (do 9, 10-49, 50 i więcej).

$\mathrm{W}$ analizie przedsiębiorstw $\mathrm{z}$ reguły mamy do czynienia $\mathrm{z}$ cenzurowaniem prawostronnym typu I ze względu na czas zakończenia obserwacji [Rossa 2005, s. 9-26; Balicki 2006, s. 71-78] - w tym przypadku przedsiębiorstwa trafiały do analizy w różnych momentach w ciągu każdego roku (kohorta), a zakończenie obserwacji przypadło na dzień 31 grudnia $2015 \mathrm{r}$. 
Tabela 1. Liczba przedsiębiorstw w latach 2001-2015

\begin{tabular}{|c|c|c|c|c|c|c|c|c|}
\hline \multirow{3}{*}{$\begin{array}{c}\text { Rok } \\
\text { powstania }\end{array}$} & \multicolumn{4}{|c|}{ Przedsiębiorstwa powstałe } & \multicolumn{4}{|c|}{ Przedsiębiorstwa zlikwidowane } \\
\hline & \multirow{2}{*}{$\begin{array}{l}\text { woje- } \\
\text { wództwo } \\
\text { łódzkie }\end{array}$} & \multicolumn{3}{|c|}{ w tym: } & \multirow{2}{*}{$\begin{array}{c}\text { woje- } \\
\text { wództwo } \\
\text { łódzkie }\end{array}$} & \multicolumn{3}{|c|}{ w tym: } \\
\hline & & Łódź & \begin{tabular}{|c|} 
Piotrków \\
Tryb. \\
\end{tabular} & \begin{tabular}{|c|}
$\begin{array}{c}\text { Skiernie- } \\
\text { wice }\end{array}$ \\
\end{tabular} & & Łódź & $\begin{array}{c}\text { Piotrków } \\
\text { Tryb. }\end{array}$ & \begin{tabular}{|c|}
$\begin{array}{c}\text { Skiernie- } \\
\text { wice }\end{array}$ \\
\end{tabular} \\
\hline Ogółem & 265295 & 102080 & 8817 & 5340 & 115596 & 41293 & 3948 & 2255 \\
\hline 2001 & 14896 & 5712 & 547 & 339 & 10282 & 3696 & 413 & 215 \\
\hline 2002 & 13553 & 5300 & 484 & 315 & 8952 & 3271 & 344 & 204 \\
\hline 2003 & 13646 & 5336 & 485 & 291 & 8977 & 3354 & 321 & 178 \\
\hline 2004 & 13261 & 5303 & 452 & 287 & 8505 & 3151 & 294 & 172 \\
\hline 2005 & 16054 & 6595 & 517 & 321 & 10219 & 3984 & 320 & 174 \\
\hline 2006 & 17122 & 6548 & 539 & 339 & 10385 & 3618 & 312 & 205 \\
\hline 2007 & 17488 & 6635 & 589 & 346 & 9827 & 3504 & 315 & 183 \\
\hline 2008 & 18751 & 6775 & 655 & 364 & 9854 & 3289 & 354 & 189 \\
\hline 2009 & 21227 & 7851 & 734 & 421 & 10274 & 3502 & 333 & 191 \\
\hline 2010 & 22734 & 8556 & 831 & 480 & 9947 & 3340 & 370 & 201 \\
\hline 2011 & 19270 & 7354 & 612 & 380 & 7219 & 2528 & 220 & 140 \\
\hline 2012 & 19049 & 7508 & 612 & 360 & 5490 & 1946 & 171 & 89 \\
\hline 2013 & 19940 & 7800 & 639 & 375 & 3729 & 1352 & 127 & 76 \\
\hline 2014 & 19396 & 7662 & 582 & 379 & 1507 & 586 & 43 & 32 \\
\hline 2015 & 18908 & 7145 & 539 & 343 & 429 & 172 & 11 & 6 \\
\hline
\end{tabular}

Źródło: [Mikulec 2017c].

\section{Mediana czasu trwania i mediana dalszego czasu trwania}

Mediana czasu trwania przedsiębiorstw (czas póltrwania) to wartość czasu trwania, którą osiąga 50\% jednostek, zaś drugie 50\% jednostek tego czasu nie osiąga, tzn. doznaje wcześniej zdarzenia likwidacji - przy czym „pół” odnosi się do zbiorowości obiektów, a nie czasu. Można ją nazwać prawdopodobnym trwaniem przedsiębiorstw.

Inaczej mówiąc, mediana jest to czas niezbędny do tego, aby kohorta przedsiębiorstw zmniejszyła się do połowy jej stanu początkowego $n_{0}$. Do wyznaczenia mediany czasu trwania kohorty nie jest potrzebna kompletna analiza kohortowa, wystarczy obserwować kohortę do momentu, aż likwidacji ulegnie 50\% jednostek wyjściowej liczebności kohorty, tj. $n_{0} / 2$. W interpretacji graficznej (rys. 1) jest to odcięta punktu przecięcia krzywych $\hat{F}_{t^{*}}$ i $\hat{S}_{t^{*}}$. Jeśli posiadamy dane w postaci tablicy kohortowej o rocznych przedziałach czasu ${ }^{1}$, to należy skorzystać ze wzoru interpolacyjnego [Balicki 1997, s. 61-62; Balicki 2006, s. 34-36; Jackowska 2013, s. 26-27]:

${ }^{1}$ Roczne kohortowe tablice trwania z reguły zawierają numery okresów $t$ oraz odpowiadające im początki $t^{*}$ przedziałów czasu $\left\langle t^{*}, t^{*}+1\right.$ ) (por. [Mikulec 2017c]). 


$$
m e=t_{d}^{*}+\frac{\left(n_{t_{d}^{*}}-0,5 n_{0}\right) h_{0}}{\left(n_{t_{d}^{*}}-n_{t_{d}^{*}+1}\right)},
$$

gdzie: $t_{d}^{*}$ - dolna granica, początek przedziału czasu trwania, dla którego wciąż pozostaje co najmniej połowa przedsiębiorstw (wyjściowej liczebności kohorty), $t_{d+1}^{*}$ - dolna granica, początek przedziału czasu trwania następującego po tym, w którym wciąż pozostaje co najmniej połowa przedsiębiorstw (wyjściowej liczebności kohorty), $n_{t_{d}^{*}}-$ przedsiębiorstwa, które dotrwały na początek okresu numer $t_{d}^{*}$, tj. przedziału czasu $\left\langle t_{d}^{*}, t_{d}^{*}+1\right)$ dla tablic rocznych, $n_{t_{d}^{*}+1}-$ przedsiębiorstwa, które dotrwały na początek okresu numer $t_{d}^{*}+1$, tj. przedziału cza$\mathrm{su}\left\langle t_{d}^{*}+1, t_{d}^{*}+2\right)$ dla tablic rocznych - przy czym pierwsza z liczb $n_{t_{d}^{*}} \geq n_{0} / 2$, a druga $n_{t_{d}^{*}+1}<n_{0} / 2, h_{0}$ - rozpiętość przedziału klasowego w tablicy kohortowej, tablice roczne $h_{0}=1$ (oznaczenia we wzorze zostały zmienione).

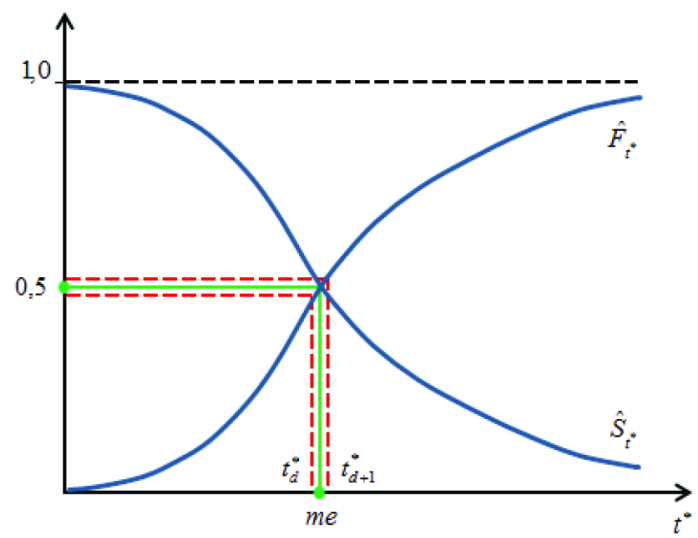

Medianę oblicza się, wykorzystując zmiany liczebności kohorty w czasie, lecz jej ideę łatwiej jest pokazać na wykresie dystrybuanty (funkcji dotrwania) i funkcji przetrwania przedsiębiorstw.

Rys. 1. Graficzna prezentacja mediany czasu trwania (półtrwania)

Źródło: opracowanie własne na podstawie [Balicki 2006, s. 36].

Mediana dalszego czasu trwania przedsiębiorstw to mediana obliczona dla dowolnego $t_{j}^{*}<t_{\max }^{*}$, którą definiuje się względem funkcji przetrwania $\hat{S}_{t^{*}}$. Jest to wartość czasu trwania od punktu $t_{j}^{*}$, w którym wartość funkcji przetrwania $\hat{S}_{t^{*}}$ będzie o 
połowę mniejsza - $0,5 \hat{S}_{t_{j}^{*}}$. Można ją nazwać prawdopodobnym dalszym trwaniem przedsiębiorstw - graficzna interpretacja (rys. 2). Jeżeli co najmniej połowa jednostek doznała zdarzenia końcowego (likwidacji) i spełniony jest warunek $\hat{S}_{t_{d}^{*}} \leq 0,5 \hat{S}_{t_{j}^{*}} \leq \hat{S}_{t_{d}^{*}+1}$ [Balicki 2006, s. 40-41; Jackowska 2013, s. 135], to:

$$
m e_{j}=t_{d}^{*}-t_{j}^{*}+\frac{\left(\hat{S}_{t_{d}^{*}}-0,5 \hat{S}_{t_{j}^{*}}\right) h_{0}}{\left(\hat{S}_{t_{d}^{*}}-\hat{S}_{t_{d}^{*}+1}\right)},
$$

gdzie: $t_{j}^{*}$ - dowolnie wybrany moment w czasie (w tablicach - dowolnie wybrany początek przedziału czasu trwania), $t_{d}^{*}$ - dolna granica, początek przedziału czasu, dla którego wciąż pozostaje więcej niż połowa przedsiębiorstw, licząc od wybranego momentu czasu $t_{j}^{*}$, a więc $0,5 \hat{S}_{t_{j}^{*}}, t_{d+1}^{*}$ - dolna granica, początek przedziału czasu następującego po tym, w którym wciąż pozostaje więcej niż połowa przedsiębiorstw, licząc od wybranego momentu czasu $t_{j}^{*}, \hat{S}_{t_{d}^{*}}, \hat{S}_{t_{d}^{*}+1}-$ wartość funkcji przetrwania przedsiębiorstwa dla okresu numer $t_{d}$ i $t_{d}+1$, a więc $\mathrm{w}$ przedziale czasu odpowiednio $\left\langle t_{d}^{*}, t_{d}^{*}+1\right)$ i $\left\langle t_{d}^{*}+1, t_{d}^{*}+2\right), h_{0}$ - rozpiętość przedziału klasowego w tablicy kohortowej, tablice roczne $h_{0}=1$ (oznaczenia we wzorze zostały zmienione) ${ }^{2}$.

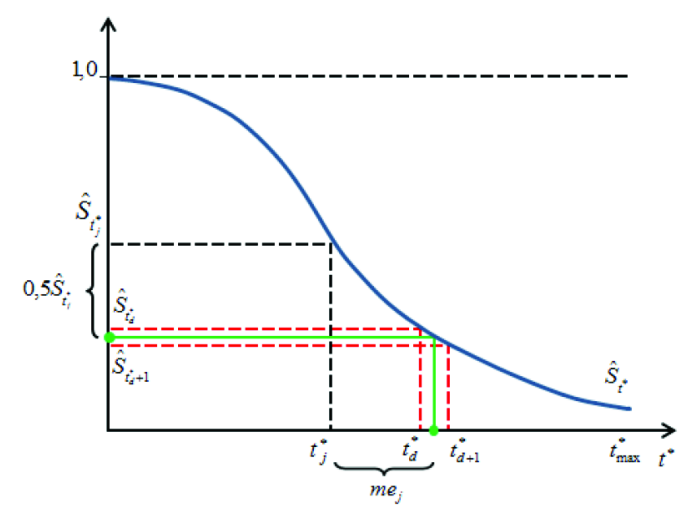

Rys. 2. Graficzna ilustracja mediany dalszego czasu trwania Źródło: opracowanie własne.

${ }^{2}$ Adaptacja wzorów (1), (2) na potrzeby trzymiesięcznych kohortowych tablic trwania wymaga rozpatrywania numerów okresów $t=0,1, \ldots, w$ oraz odpowiadających im przedziałów czasu $\left\langle t^{*}, t^{*}+3\right),\left\langle t^{*}+3, t^{*}+6\right)$, itd. (por. [Mikulec 2017b]). 


\section{Wyniki analizy dla przedsiębiorstw $\mathrm{z}$ województwa lódzkiego, w tym z Lodzi, Piotrkowa Trybunalskiego i ze Skierniewic}

W tabeli 2 podane są wyniki dla mediany czasu trwania przedsiębiorstw (według roku powstania). Wartości w wierszach tablic maleją dla kolejnych kohort przedsiębiorstw ze względu na wspólną datę zakończenia obserwacji - 31 grudnia 2015 r., stąd też ewentualnych porównań należy dokonywać pomiędzy jednostkami województwa łódzkiego i miast na prawach powiatu.

Tabela 2. Mediana czasu trwania (w latach) dla kolejnych kohort przedsiębiorstw

\begin{tabular}{|c|c|c|c|c|c|c|c|c|}
\hline \multirow{2}{*}{ Wyszczególnienie } & \multicolumn{7}{|c|}{ Rok powstania } \\
\cline { 2 - 10 } & 2001 & 2002 & 2003 & 2004 & 2005 & 2006 & 2007 & 2008 \\
\hline Województwo lódzkie & $\mathbf{8 , 6 1}$ & $\mathbf{7 , 8 5}$ & $\mathbf{7 , 0 1}$ & $\mathbf{6 , 7 6}$ & $\mathbf{6 , 2 2}$ & $\mathbf{6 , 3 2}$ & $\mathbf{6 , 6 2}$ & $\mathbf{6 , 6 2}$ \\
\hline w tym: Łódź & 8,97 & 8,67 & 7,61 & 7,92 & 7,01 & 7,63 & 7,52 & - \\
\hline Piotrków Trybunalski & 6,48 & 6,23 & 6,08 & $4,96^{*}$ & 6,21 & 6,84 & 7,24 & 6,29 \\
\hline Skierniewice & $10,30^{*}$ & 8,71 & 8,82 & 8,32 & 8,68 & 6,74 & 6,88 & 6,94 \\
\hline
\end{tabular}

Źródło: obliczenia własne (Excel) na podstawie wyników badania.

Okazuje się, że kohorta przedsiębiorstw powstałych w 2008 roku była ostatnią, dla której możliwe było obliczenie mediany czasu trwania ${ }^{3}$. W przypadku Łodzi i Skierniewic przedsiębiorstwa (z kolejnych generacji) charakteryzowały się wyższą wartością mediany niż jednostki z całego województwa. Oznacza to, że czas trwania, który osiągało $50 \%$ jednostek z tych miast, był dłuższy niż dla jednostek w województwie łódzkim. W przypadku Piotrkowa Trybunalskiego jedynie dla kohort przedsiębiorstw powstałych w latach 2006-2007 miała miejsce omówiona wyżej sytuacja - wartości mediany były wyższe niż dla firm w województwie.

Warto zwrócić uwagę na najwyższą (10,30 roku), a szczególnie na najniższą (4,96 roku) wartość mediany dla kolejnych kohort przedsiębiorstw z Łodzi, Piotrkowa Trybunalskiego i ze Skierniewic (oznaczone "*” w tablicy), która wcale nie występuje dla ostatniej kohorty w tablicy. Informuje ona o tym, że spośród firm powstałych w 2004 r. w Piotrkowie Trybunalskim 50\% jednostek funkcjonowało na rynku co najmniej 4,96 roku, jednak ,drugie tyle”, a więc aż 50\% jednostek, wspomnianego czasu trwania (4,96 roku) nie osiągnęło. Z kolei wartość $m e=10,30$ roku wskazuje, że spośród przedsiębiorstw powstałych w $2001 \mathrm{r}$. w Skierniewicach 50\% jednostek funkcjonowało na rynku co najmniej (aż) 10,30 roku, natomiast pozostałe $50 \%$ jednostek tego czasu trwania nie osiągnęło, uległy likwidacji wcześniej.

\footnotetext{
${ }^{3}$ Miejsca w tablicy (tab. 2, tab. 3) opatrzone znakiem "-" to przypadki, w których wyznaczenie odpowiednio mediany czasu trwania lub mediany dalszego czasu trwania było niemożliwe.
} 
Tabela 3. Mediana dalszego czasu trwania (w latach) dla kolejnych kohort przedsiębiorstw

\begin{tabular}{|c|c|c|c|c|c|c|c|c|}
\hline \multirow{2}{*}{$\begin{array}{c}\text { Początek przedziału } \\
\text { czasu trwania (lata) } \\
\qquad\left\langle t_{j}^{*}, t_{j}^{*}+1\right)\end{array}$} & \multicolumn{8}{|c|}{ Rok powstania } \\
\hline & 2001 & 2002 & 2003 & 2004 & 2005 & 2006 & 2007 & 2008 \\
\hline \multicolumn{9}{|c|}{ województwo łódzkie } \\
\hline 0 & 8,61 & 7,85 & 7,01 & 6,76 & 6,22 & 6,32 & 6,62 & 6,62 \\
\hline 1 & $7,91^{*}$ & $7,55^{*}$ & $6,95^{*}$ & $6,74^{*}$ & 6,59 & $6,55^{*}$ & 6,74 & - \\
\hline 2 & $7,62^{* *}$ & $7,46^{* *}$ & $7,01^{* *}$ & $7,84^{* *}$ & 7,63 & 7,58 & - & - \\
\hline 3 & $7,21^{* * *}$ & $7,27^{* * *}$ & 7,62 & - & - & - & - & - \\
\hline 4 & $6,77^{\Delta}$ & $7,63^{\Delta}$ & - & - & - & - & - & - \\
\hline 5 & 6,82 & - & - & - & - & - & - & - \\
\hline 6 & 7,22 & - & - & - & - & - & - & - \\
\hline 7 & 7,86 & - & - & - & - & - & - & - \\
\hline \multicolumn{9}{|c|}{ Łódź } \\
\hline 0 & 8,97 & 8,67 & 7,61 & 7,92 & 7,01 & 7,63 & 7,52 & - \\
\hline 1 & $8,97^{*}$ & $8,66^{*}$ & $7,75^{*}$ & $8,11^{*}$ & 7,41 & $7,94^{*}$ & - & - \\
\hline 2 & $8,99^{* *}$ & $8,79^{* *}$ & $8,09^{* *}$ & $9,24^{* *}$ & - & - & - & - \\
\hline 3 & $8,62^{* * *}$ & $8,84^{* * *}$ & 8,59 & - & - & - & - & - \\
\hline 4 & $8,34^{4}$ & $9,71^{\Delta}$ & - & - & - & - & - & - \\
\hline 5 & 8,43 & - & - & - & - & - & - & - \\
\hline \multicolumn{9}{|c|}{ Piotrków Trybunalski } \\
\hline 0 & 6,48 & 6,23 & 6,08 & 4,96 & 6,21 & 6,84 & 7,24 & 6,29 \\
\hline 1 & $6,05^{*}$ & $5,80^{*}$ & $6,29^{*}$ & $5,77^{*}$ & 7,07 & $7,38^{*}$ & - & 6,75 \\
\hline 2 & $5,70^{* *}$ & $6,24^{* *}$ & $6,90^{* *}$ & $8,80^{* *}$ & - & - & - & - \\
\hline 3 & $5,53^{* * *}$ & $5,74^{* * *}$ & 8,95 & - & - & - & - & - \\
\hline 4 & $5,16^{\Delta}$ & $7,21^{\Delta}$ & - & - & - & - & - & - \\
\hline 5 & 6,58 & - & - & - & - & - & - & - \\
\hline 6 & 7,32 & - & - & - & - & - & - & - \\
\hline \multicolumn{9}{|c|}{ Skierniewice } \\
\hline 0 & 10,30 & 8,71 & 8,82 & 8,32 & 8,68 & 6,74 & 6,88 & 6,94 \\
\hline 1 & $10,35^{*}$ & $8,85^{*}$ & $8,95^{*}$ & $7,96^{*}$ & - & $6,72^{*}$ & 8,00 & - \\
\hline 2 & $10,41^{* *}$ & $8,62^{* *}$ & $9,54^{* *}$ & $8,56^{* *}$ & - & - & - & - \\
\hline 3 & $10,08^{* * *}$ & $8,40^{* * *}$ & - & - & - & - & - & - \\
\hline 4 & $9,69^{\Delta}$ & $8,93^{\Delta}$ & - & - & - & - & - & - \\
\hline
\end{tabular}

Źródło: obliczenia własne (Excel) na podstawie wyników badania.

Warto zwrócić uwagę, że mediana jako miara pozycyjna jest niewrażliwa na wartości odstające (skrajne), w przypadku tej analizy pomija dane cenzurowane - o przedsiębiorstwach, które trwały nadal, poza datą zakończenia obserwacji. Stąd też choć jest liczona dla kohort przedsiębiorstw powstałych w danym roku, to de 
facto wykorzystuje informacje tylko o przedsiębiorstwach, które powstały i uległy likwidacji (por. wzór (1) i wyniki tab. 2). Uzyskane wyniki mogą zatem stanowić uzupełnienie dla wyników średniego czasu trwania przedsiębiorstw powstałychzlikwidowanych w latach 2001-2008 [Mikulec 2017a] . $^{4}$

Wartości mediany dalszego czasu trwania przedsiębiorstw zamieszczone zostały $\mathrm{w}$ tab. 3. Wartości w pierwszych wierszach tablicy dla przedsiębiorstw z województwa łódzkiego, Łodzi, Piotrkowa Trybunalskiego i ze Skierniewic, z zerowym czasem trwania (0), pokrywają się z wartościami mediany czasu trwania firm (tab. 2) jest to rzecz naturalna, podobnie jak zmniejszanie się wartości prawdopodobnego dalszego trwania przedsiębiorstw dla jednostek $\mathrm{z}$ czasem trwania 1, 2, 3 itd. ze względu na wspólną datę zakończenia obserwacji - 31 grudnia $2015 \mathrm{r}$.

Analizując uzyskane wyniki (analiza pionowa), należy zauważyć, że nie we wszystkich podgrupach udało się obliczyć medianę dalszego czasu trwania przedsiębiorstw. W przypadku województwa łódzkiego było to możliwe dla jednostek, które dotrwały na początek $1 .-8$. roku ${ }^{5}$, w przypadku Łodzi dla firm, które dotrwały na początek 1. -6. roku, w odniesieniu do Piotrkowa Trybunalskiego dla przedsiębiorstw, które dotrwały na początek 1. -7. roku, a w odniesieniu do Skierniewic dla jednostek, które dotrwały na początek 1.-5. roku - kohorta z 2001 r. Aby wyciągnąć wnioski z przeprowadzonej analizy, należy zatem porównywać wartości w tych samych polach tablicy - dla różnych podgrup firm.

Przeglądając zatem wyniki wspólne dla wszystkich podgrup przedsiębiorstw z Lodzi, Piotrkowa Trybunalskiego i ze Skierniewic, funkcjonujących na rynku co najmniej 1 rok (tab. 3, od wiersza drugiego w każdej części - wartości zacieniowane) na tle firm $z$ województwa łódzkiego, można zauważyć, że:

- Jednostki z kohort 2001-2004 i 2006, które dotrwały na początek 2. roku działalności gospodarczej, pochodzące z Łodzi i ze Skierniewic miały wyższą wartość prawdopodobnego dalszego trwania niż przedsiębiorstwa w całym województwie; w przypadku firm z Piotrkowa Trybunalskiego sytuacja taka zachodziła jedynie dla generacji z 2006 r. (7,38 roku wobec 6,55 roku) - wartości w tablicy oznaczone ${ }^{(*)}$.

- Firmy z kohort 2001-2004, które dotrwały na początek 3. roku działalności gospodarczej, powstałe w Lodzi i Skierniewicach, również miały wyższą wartość mediany dalszego czasu trwania niż przedsiębiorstwa w całym województwie; w przypadku jednostek z Piotrkowa Trybunalskiego tego typu sytuacja zachodzi-

\footnotetext{
${ }^{4}$ Praca zawiera wyniki analizy wskaźnikowej trwania przedsiębiorstw w województwie łódzkim w latach 2001-2015, ze szczególnym uwzględnieniem miast na prawach powiatu: Łodzi, Piotrkowa Trybunalskiego oraz Skierniewic.

${ }^{5}$ Należy pamiętać, że numeracja okresów oraz czas trwania w tablicach kohortowych (oraz w boczku tab. 3) rozpoczynają się od 0 - według czasu własnego przedsiębiorstw, stąd też pierwszy rok funkcjonowania przedsiębiorstw według czasu kalendarzowego (i w potocznym rozumieniu) trwa od 0 do 1. Dla ułatwienia interpretacja wyników została zapisana według czasu kalendarzowego.
} 
ła tylko dla generacji z 2004 r. (8,80 roku wobec 7,84 roku) - wartości w tablicy oznaczone ${ }^{(* *)}$.

- Przedsiębiorstwa z kohort 2001-2002, które dotrwały na początek 4. i 5. roku działalności gospodarczej, pochodzące z Łodzi i ze Skierniewic, także miały wyższą wartość prawdopodobnego dalszego trwania niż jednostki w całym województwie - wartości w tablicy oznaczone odpowiednio ${ }^{(* * *)} \operatorname{oraz}^{\left({ }^{(}\right)}$.

\section{Wzory dla pozostałych kwartyli rozkladu czasu trwania}

Należy zauważyć, że wzory na medianę czasu trwania oraz medianę dalszego czasu trwania przedsiębiorstw mogą stanowić podstawę do przekształcenia ich we wzory na kwartyl pierwszy, czy też kwartyl trzeci czasu trwania i dalszego czasu trwania firm - a gdyby to było podyktowane celem prowadzonych analiz, można również wyznaczyć kwantyl dowolnego innego rzędu [Balicki 2006, s. 36; Mikulec 2017d].

W celu wyznaczenia kwartyla pierwszego czasu trwania firm należy obserwować zmniejszanie się kohorty do momentu likwidacji co najmniej $25 \%$ jednostek, tj. $n_{0} / 4$. Określić $t_{d}^{*}$ jako początek przedziału czasu trwania, dla którego wciąż pozostaje co najmniej $25 \%$ przedsiębiorstw, oraz początek przedziału następnego $\mathrm{w}$ tablicy kohortowej $t_{d+1}^{*}$. Do obliczeń przyjąć liczby przedsiębiorstw pochodzące z tych przedziałów i spełniające warunki $n_{t_{d}^{*}} \geq n_{0} / 4$ i $n_{t_{d}^{*}+1}<n_{0} / 4$ oraz właściwy dla kwartyla pierwszego próg $0,25 n_{0}$. Graficzną interpretację kwartyla pierwszego można pokazać poprzez funkcję $\hat{F}_{t^{*}}$ lub funkcję gęstości.

Analogicznie w przypadku kwartyla pierwszego dalszego czasu trwania przedsiębiorstw, należy wybrać dowolny początek przedziału czasu $t_{j}^{*}<t_{\max }^{*} \mathrm{z}$ odpowiadającą mu wartością $\hat{S}_{t_{j}^{*}}$. Następnie obserwować wartość czasu trwania od punktu $t_{j}^{*}$, aby wartość funkcji przetrwania $\hat{S}_{t^{*}}$ zmniejszyła się o jedną czwartą $-0,25 \hat{S}_{t_{j}^{*}}$. Jeśli spełniony jest warunek $\hat{S}_{t_{d}^{*}} \leq 0,25 \hat{S}_{t_{j}^{*}} \leq \hat{S}_{t_{d}^{*}+1}$, to po podstawieniu wartości $\hat{S}_{t_{d}^{*}}, \hat{S}_{t_{d}^{*}+1}$ oraz właściwego dla kwartyla pierwszego progu $0,25 \hat{S}_{t_{j}^{*}}$ wyznacza się omawiany parametr. Interpretację graficzną kwartyla pierwszego dalszego czasu trwania można również oprzeć na rys. 2.

\section{Zakończenie}

Wyznaczanie dodatkowych parametrów rozkładu czasu trwania oraz warunkowego rozkładu czasu trwania przedsiębiorstw na podstawie wyników tablic kohortowych 
stanowi rozszerzenie idei samych tablic, które zawierają oszacowania podstawowych funkcji z zakresu analizy trwania.

Najczęściej wyznacza się prawdopodobne trwanie przedsiębiorstw i prawdopodobne dalsze trwanie przedsiębiorstw oraz przeciętny dalszy czas trwania firm (obliczenia dla ostatniego parametru powinny być jednak prowadzone na danych pełnych - jednostkach, które doznały zdarzenia likwidacji w analizowanym okresie, stąd też zagadnienie to będzie przedmiotem oddzielnego opracowania). W artykule wskazano również na możliwość wyznaczania na podstawie wyników tablic kohortowych także pozostałych kwartyli, czy mówiąc ogólnie, kwantyli rozkładu czasu trwania.

Uzyskane wyniki pozwoliły wskazać na różnice w zakresie czasu trwania „połowy” przedsiębiorstw, czy też dalszego czasu trwania „połowy” przedsiębiorstw z poszczególnych kohort z Łodzi, Piotrkowa Trybunalskiego i ze Skierniewic, na tle jednostek z województwa łódzkiego. Sytuacja poszczególnych generacji jednostek z Łodzi i ze Skierniewic była bardziej korzystna na tle przedsiębiorstw z województwa łódzkiego (wyższe wartości median), natomiast jednostki z większości analizowanych kohort z Piotrkowa Trybunalskiego charakteryzowały się niższymi wartościami wyznaczonych median czasu trwania.

W toku dalszych analiz zostaną podjęte próby wskazania czynników wpływających na czas trwania przedsiębiorstw z poszczególnych kohort z Łodzi, Piotrkowa Trybunalskiego i ze Skierniewic, na tle jednostek z województwa łódzkiego, z wykorzystaniem podejścia modelowego.

\section{Literatura}

Balicki A., 1997, Zastosowanie metod analizy kohortowej do badania czasu pozostawania bez pracy, Wiadomości Statystyczne, nr 7(434), s. 53-62.

Balicki A., 2006, Analiza przeżycia i tablice wymieralności, PWE, Warszawa.

Jackowska B., 2013, Modele dalszego trwania życia oraz ich zastosowania w przypadku osób starszych, Wydawnictwo Uniwersytetu Gdańskiego, Gdańsk.

Jackowska B., 2015, Analiza kohortowa czasu istnienia mikroprzedsiębiorstw w Gdańsku, Zarządzanie i Finanse. Journal of Management and Finance, vol. 13, no. 4/2, s. 127-145.

Mikulec A., 2017a, Analiza wskaźnikowa trwania przedsiębiorstw w województwie łódzkim, Wiadomości Statystyczne, nr 11(678), s. 29-55.

Mikulec A., 2017b, Kohortowe tablice trwania przedsiębiorstw w województwie tódzkim - ujęcie kwartalne, Prace Naukowe Uniwersytetu Ekonomicznego we Wrocławiu, nr 468, Taksonomia 28, Klasyfikacja i analiza danych - teoria $i$ zastosowania, red. K. Jajuga, M. Walesiak, UE, Wrocław, s. 147-160.

Mikulec A., 2017c, Kohortowe tablice trwania przedsiębiorstw w województwie tódzkim w ujęciu rocznym, Wiadomości Statystyczne (praca w druku).

Mikulec A., 2017d, Kwartyle rozkładu czasu trwania $i$ warunkowego rozkładu czasu trwania przedsiębiorstw, https://doi.org/10.13140/RG.2.2.17785.16489 (03.02.2018).

Rossa A., 2005, Metody estymacji rozkładu czasu trwania zjawisk dla danych cenzurowanych oraz ich zastosowania, Rozprawy Habilitacyjne Uniwersytetu Łódzkiego, Wydawnictwo Uniwersytetu Łódzkiego, Łódź. 